\title{
Transglutaminase addition increases quality and acceptation of sausages obtained from mechanically separated meat of hybrid sorubins
}

\author{
Angela Dulce Cavenaghi-Altemio', Alana Ávalo Hashinokuti ${ }^{1}$, Daniele Menezes Albuquerque ${ }^{2}$, \\ Gustavo Graciano Fonseca ${ }^{3 *}$ \\ ${ }^{1}$ Laboratory of Food Technology, Faculty of Engineering, Federal University of Grande Dourados, Dourados, MS, Brazil, ${ }^{2}$ Faculty of \\ Agrarian Sciences, Federal University of Grande Dourados, Dourados, MS, Brazil, ${ }^{3}$ Laboratory of Bioengineering, Faculty of Biological and \\ Environmental Sciences, Federal University of Grande Dourados, Dourados, MS, Brazil
}

\section{A B S T R A C T}

\begin{abstract}
This work aimed at evaluating the chemical and physical parameters of sausages prepared with mechanically separated meat (MSM) from hydrid sorubim fish without $(0.0 \%)$ or with the addition of the transglutaminase enzyme at $0.3 \%$ and $0.6 \%$, and at analyzing the sensory and the acceptance parameters of these products. The addition of transglutaminase differed significantly in the chemical composition $(\mathrm{P}<0.05)$. The protein content gradually decreased from 21.83 to $19.23 \%$ while the shear strength increased from 2.02 to $2.95 \mathrm{~N}$ with the transglutaminase addition. Moreover, due to combination with salt and phosphate, it promoted a slight influence on the colour of the obtained product, so that the brightness, the yellowness and the redness increased in the formulations added of the enzyme $(0.3$ and $0.6 \%)$ presented better results compared to the formulation without addition of the enzyme. Sensory analysis indicated that there was significant difference in the attributes texture and flavor, being recorded higher average values for treatments with the addition of transglutaminase $(0.3$ and $0.6 \%)$ in relation to the treatment absence of this enzyme $(P<0.05)$. The acceptance rate for sausages which had transglutaminase in the formulation ranged between 79.86 and $84.03 \%$, indicating a high acceptance. Sausages containing transglutaminase in the formulation obtained a higher purchasing intention from the consumers $(66 \%)$.
\end{abstract}

Keywords: Fish; Texture; Sensory analysis; Microbiological analysis; Transglutaminase

\section{INTRODUCTION}

Mechanically separated meat (MSM) of fish is the meat pulp obtained by the mechanical separation of the edible parts of a single species, or a mixture of fish species with similar sensory characteristics, free of bones, viscera, scales and skin (Tenuta Filho and Jesus, 2003). The possibility of exploitation the fish pulp stimulates the development of new products by the industry, reaching new market segments, and attending the social demand for highquality protein of animal origin (Macedo and Sato, 2005; Oetterer, 2006).

Due to the high production costs, and the need for practical products of rapid preparation by consumer, the industries have developed and applied new process technologies to reduce losses and increase profits (Ferreira et al., 2012).
In this sense, the development of emulsified inlaids from MSM of fish is a practical and feasible alternative related to the quality of foods and total utilization of fish.

The transglutaminase enzyme is one of the existing innovations in food technology that stands out for its capability of restructuring the texture of food products, allowing the use low-cost raw material (Macedo and Sato, 2005). This transferase enzyme has the ability to catalyze crosslinking bonds that strengthen the meat protein network, resulting in increased firmness and elasticity, improving cutting and slicing of the products (Marapana and Jiang, 2004). Moreover, the application of this enzyme results in many changes in the physical properties of the food, e.g., water retention capacity, gel strength, texture, viscosity and thermal stability. For the consumer market these are the most important characteristic related the quality of food, mainly the texture (Herranz et al., 2013).

\footnotetext{
*Corresponding author:

Gustavo Graciano Fonseca, Federal University of Grande Dourados, Faculty of Biological and Environmental Sciences, CEP 79.804-970, Dourados, MS, Brazil.Phone: (55 67) 3410-2227, Fax: (55 67) 3410-2190, E-mail: ggf@ufgd.edu.br
}

Revised: 21 April 2018; $\quad$ Accepted: 30 September 2018 
The addition of the enzyme transglutaminase (TG) is an alternative to the processing of emulsified inlaids (fish sausage type). The application of transglutaminase provides the development of products that add value to whole fish, including meat carcasses and waste filleting (Gaspar and Góes-Favarini, 2015).

Thus, this work aimed at evaluating the chemical and physical parameters of sausages prepared with MSM from hydrid sorubim fish added or not of the transglutaminase enzyme, and at analyzing the sensory and the acceptance parameters of these products.

\section{MATERIAL AND METHODS}

\section{Mechanically separated meat (MSM) of hybrid sorubim} Hybrid sorubim (Psendoplatystoma reticulatum $\mathrm{x}$ Psendoplatystoma corruscans) carcasses were supplied by a local fishery processing plant. They were transported to the Laboratory of Bioengineering from the Federal University of Grande Dourados, Dourados, MS, Brazil, under refrigerated conditions, and immediately utilized to produce MSM. The MSM was produced in $3 \mathrm{~mm}$ particle size using a meat-bone separator (HT 250, High Tech, Brazil), operating at inlet $6^{\circ} \mathrm{C}$ and outlet $10^{\circ} \mathrm{C}$ (Cortez-Vega et al., 2013).

\section{Sausages}

Sausages were prepared using the following formulation 1 (F1) (in \%,w/w): 87.7 MSM of hybrid sorubim, 4.0 soybean protein concentrate, 2.0 cassava starch, $2.0 \mathrm{NaCl}, 1.7$ spices, 0.5 sodium erythorbate, 0.5 carrageenan, 0.5 sodium polyphosphate, 0.5 sodium nitrate, 0.4 sucrose, 0.2 cochineal carmine. Beyond that, $0.3 \%$ (w/w) (formulation 2, F2) and $0.6 \%(\mathrm{w} / \mathrm{w}$ ) (formulation 3, F3) of the enzyme transglutaminase were added to F1. Additives and condiments were provided by the companies Conatril Food Industry Ltd. and IBRAC - Brazilian Industry of Additives and Condiments Ltd., both from Rio Claro, SP. The enzyme transglutaminase was obtained from the company Ajinomoto.

MSM was thawed at $10^{\circ} \mathrm{C}$ until reach $0^{\circ} \mathrm{C}$ just before sausage manufacture. After weighed, it was emulsified in a cutter (brand Sire) together with the other ingredients of the formulations, until form a homogenized emulsion, in approximately 4 min.

The emulsion was stuffed into inlaids, cellulose casings type, with $26 \mathrm{~mm}$ diameter and $180 \mathrm{~mm}$ length (Viskase, Brazil), and processed with manual inlaid equipment (Pizelli, Brazil). Then, sausages were cooked at $65^{\circ} \mathrm{C}$ in water bath (Quimis model Q.215-2, Brazil) until the colour development. After that, temperature was increased and maintained at $85^{\circ} \mathrm{C}$ until internal temperature of sausages reached $74^{\circ} \mathrm{C}$. After cooking, the sausages were cooled and pasteurized by heat shock with cold water.

The dyeing was carried out with the vegetable dye annatto $5 \%$ for $20 \mathrm{~min}$. Then the sausages were dipped in a phosphoric acid solution with a $\mathrm{pH}$ ranging between 2 and 3 . The sausages were kept under refrigeration at $4^{\circ} \mathrm{C}$ for 12 hours, vacuum packed in polyethylene bags, labeled, and stored at $4^{\circ} \mathrm{C}$ for microbial and texture determinations. For proximate composition and sensory evaluation frankfurters were stored at $-18^{\circ} \mathrm{C}$ until analyzed.

\section{Chemical analyzes}

\section{Proximate composition}

Moisture, crude protein, and crude ash contents of the sausages were determined in triplicate according to the methods described by AOAC (1995). Moisture was determined by the oven drying method at $105^{\circ} \mathrm{C}$ until constant weight (method 950.46), protein by the Kjeldhal method (method 928.08) and ash by using the muffle oven technique (method 920.153). The lipid content was obtained in triplicate by the extraction method with cold organic solvent (Bligh and Dyer, 1959).

\section{$\mathrm{pH}$ values}

$\mathrm{pH}$ of the sausages was measured in triplicate using a digital pH meter (Instrutherm, São Paulo, Brazil).

\section{Physical analyses}

Instrumental colour

The colour [CIE L*(lightness), a* (redness), b* (yellowness)] of the sausages was evaluated using a colorimeter (Minolta Chroma Meter CR 410), with measurements standardized with respect to the white calibration plate (Jiménez and Gutiérrez, 2001). Three readings were made from the homogenized samples, after removing the external involucre.

\section{Shear strength}

Texture analysis of the sausages was carried out using a texture analyzer Model TAXTplus (Stable Micro Systems, Surrey, England) calibrated with a standard weight of $5 \mathrm{~kg}$. Sausages kept at $2^{\circ} \mathrm{C}$ were equilibrated at room temperature $\left(28-30^{\circ} \mathrm{C}\right)$ before analysis. Cylindrical samples, $2.5 \times 2.0 \mathrm{~cm}$, were cut, placed in the texture analyzer and submitted to a cutting/shearing test (speed of $2.0 \mathrm{~mm} / \mathrm{s}$, distance of $16 \mathrm{~mm}$ ) using a Warner-Bratzler shear blade (1 mm thick) to determine the shear strength $(\mathrm{N})$, which indicated the firmness of the sample. A minimum of 10 replicates of each formulation were analyzed (Pedroso and Demiate, 2008).

\section{Microbiological analysis}

Microbiological analyses of the sausages were performed for thermo-tolerant coliforms and Salmonella sp. in 
accordance with the methodology described elsewhere (USDA/FSIS, 1998).

\section{Sensory analysis}

Sensory analyses of the sausages were conducted by 48 non-trained panelists. A nine-point hedonic scale $(9=$ like extremely; 1 =dislike extremely) was used for evaluation of the overall acceptability. Samples (2 cm long pieces) were prepared by steeping the emulsified inlaid in boiling water for 3 min, draining the liquid and holding on a warming tray in covered plates for no longer than $30 \mathrm{~min}$, and served in disposable containers, coded with three digit random numbers (Granato et al., 2012). The evaluated attributes were colour, odor, texture and taste.

Overall acceptation was evaluated in terms of purchase intention using a 5 -point scale, where $5=$ certainly would purchase, $4=$ probably would purchase, $3=$ perhaps would purchase/perhaps would not purchase, $2=$ probably would not purchase and 1 = certainly would not purchase, which was expressed as the percentage of total score. The acceptation index (AI) was calculated according to the following equation: $\mathrm{AI}=$ (average of the attributed grades/maximum attributed grade) x 100 . The sample was considered accepted if the value was greater than $70 \%$ (Stone and Sidel, 1993).

\section{Statistical analysis}

The assumptions of normality and homogeneity at 5\% of the residues were verified by the Shapiro-Wilk and Levene tests and analyzed by ANOVA, and means were compared by the Tukey test at 5\% using the statistical software Statistica 7.0.

\section{RESULTS AND DISCUSSION}

\section{Chemical analysis}

The results of the chemical composition (moisture, proteins, lipids and ashes) of sausages produced with mechanically separated meat (MSM) of hybrid sorubim are shown in Table 1.

The observed differences in chemical composition (Table 1) between the formulations can be justified by the difference in the utilized raw materials (MSM) in the preparation of the sausages.
The average values for moisture content of the sausage formulations differed significantly $(\mathrm{P}<0.05)$ between them (Table 1). In the formulation added of $0.6 \%$ transglutaminase (F3), moisture was superior to the $65 \%$ recommended by the Brazilian legislation. However, in the formulation added of $0.3 \%$ transglutaminase (F2) and the one where the enzyme was absent (F1), the legislation was attended (Brazil, 2000).

The protein content gradually decreased $(\mathrm{P}<0.05)$ from 21.83 to $19.23 \%$ with the transglutaminase addition (Table 1). According to the Brazilian legislation, the minimum protein content required for MSM (MSM) in meat products is $12 \%$ (Brazil, 2000). The values obtained values for protein were quite superior and are considered satisfactory. Mean values of $19.34 \%$ crude protein were found for sausages with MSM of Nile tilapia (Uyhara et al., 2008). It was also reported sausages with MSM of Nile tilapia with $13.29 \%$ crude protein (Cavenaghi-Altemio et al., 2013). The higher protein levels for hybrid sorubim sausages than those produced with MSM of tilapia are mainly due the composition of the flesh of the two animals and differences in the formulations.

The average values of lipids found in this study ranged from $6.99 \%$ to $11.35 \%$ (Table 1 ) are within the limits determined by Brazilian legislation (Brazil, 2000), which establishes a maximum of $30 \%$. It was found elsewhere lipid content of $3.45 \%$ (Uyhara et al., 2008) and 2.65\% in sausages formulations developed with MSM of Nile tilapia (Cavenaghi-Altemio et al., 2013). These levels were lower than those obtained for other sausages prepared with other raw materials (TBCA-USP, 2005). Again, the variations in protein and lipid contents are due to the variation of the raw material, beyond the differences in the formulations.

The results obtained for ash content were 3.72\%, 3.89\% and $4.24 \%$ for the formulations F1, F2 and F3, respectively (Table 1). Average values of ashes of $7.56 \%$ to $8.00 \%$ were reported for sausages formulations developed with MSM of Nile tilapia (Cavenaghi-Altemio et al., 2013). These high levels of ash in Nile tilapia sausages were due to the added cure salts that increase the mineral content.

\section{Physical analysis}

The results of means and standard deviations for physical parameters of instrumental colour, $\mathrm{pH}$, and texture (shear strength) are shown in Table 2.

\begin{tabular}{|c|c|c|c|c|c|}
\hline Formulation & Transglutaminase(\%) & Moisture (\%) & Protein (\%) & Lipid (\%) & Ash (\%) \\
\hline $\mathrm{F} 1$ & 0.0 & $64.69 \pm 0.56^{B}$ & $21.830 .63^{A, B}$ & $9.33 \pm 0.79^{A}$ & $3.72 \pm 0.11^{\mathrm{B}}$ \\
\hline $\mathrm{F} 2$ & 0.3 & $62.96 \pm 0.63^{c}$ & $21.36 \pm 0.77^{A}$ & $11.35 \pm 0.33^{A}$ & $3.89 \pm 0.23^{A, B}$ \\
\hline F3 & 0.6 & $69.20 \pm 0.44^{\mathrm{A}}$ & $19.23 \pm 0.67^{\mathrm{B}}$ & $6.99 \pm 0.76^{\mathrm{B}}$ & $4.24 \pm 0.09^{A}$ \\
\hline
\end{tabular}

Means with the same letter in the same column do not statistically differ at $5 \%(P>0.05)$; F1: formulation 1; F2: formulation 2; F3: formulation 3 
The values of $\mathrm{L}^{*}$ (lightness), $\mathrm{a}^{*}$ (redness), $\mathrm{b}^{*}$ (yellowness) and $\mathrm{W}$ (whiteness) showed significant difference $(\mathrm{P}<0.05)$ in all formulations. The lightness of sausages increased $(\mathrm{P}>0.05)$ as the percentage of the transglutaminase enzyme increased in the formulations. Fuentes-Zaragoza et al. (2009) studied the concentration of additives and ingredients on the colour of hake (Merluccius australis) heat treated and found significant differences in the lightness values. Redness increased $(\mathrm{P}>0.05)$ in the sausages with $0.3 \%$ transglutaminase and decreased in the sausages with $0.6 \%$ transglutaminase when compared to the sausages absent of the enzyme, while the yellowness did not differ significantly $(\mathrm{P}>0.05)$ in the different formulations (Table 2).

The addition of transglutaminase presented a slight influence on the colour of the product, so that the lightness, yellowness and redness of the sausages increased in the formulations with the transglutaminase enzyme $(0.3 \%$ and $0.6 \%$ ) when compared with the formulation without enzyme addition. In this case, the combination of salt and phosphate, potentiated by transglutaminase, had a positive and synergistic effect on meat binding and on the oxidation of myoglobin present in meat, inhibiting lipid peroxidation and improving colour (Nielsen et al., 1995; Rashchi and Finch, 2000; Keeton, 2001; Baublits et al., 2005; Kutemeyer et al., 2005; Ferreira et al., 2012).

The treatments that had added the transglutaminase enzyme at 0.3 and $0.6 \%$ did not differ $\mathrm{pH}$ significantly $(\mathrm{P}>0.05)$. The $\mathrm{pH}$ values obtained were 6.54 and 6.58 , respectively (Table 2). Only the formulation without transglutaminase addition presented a significantly different $(\mathrm{P}<0.05) \mathrm{pH}$ value (6.46; Table 2). Higher $\mathrm{pH}$ values were observed for sausages developed with MSM of Nile tilapia (CavenaghiAltemio et al., 2013).

The texture analysis was represented by the shear strength $(\mathrm{N})$ (Table 2). The values of shear strength for the formulations with the addition of transglutaminase showed no significant

\begin{tabular}{|c|c|c|c|c|}
\hline \multirow[t]{2}{*}{ Parameter } & \multicolumn{3}{|c|}{ Transglutaminase (\%) } & \multirow[t]{2}{*}{$P$-value* } \\
\hline & 0.00 (F1) & 0.30 (F2) & $0.60(F 3)$ & \\
\hline$L^{*}$ & $38.48 \pm 0.40^{\circ}$ & $49.70 \pm 0.15^{b}$ & $51.90 \pm 0.14^{a}$ & 0.0000 \\
\hline$a^{*}$ & $20.29 \pm 0.05^{c}$ & $21.79 \pm 0.08^{a}$ & $20.89 \pm 0.06^{b}$ & 0.000 \\
\hline$b^{*}$ & $15.13 \pm 0.19^{c}$ & $17.74 \pm 0.08^{a}$ & $17.18 \pm 0.06^{b}$ & 0.000 \\
\hline $\mathrm{pH}$ & $6.46 \pm 0.03^{b}$ & $6.54 \pm 0.01^{a}$ & $6.58 \pm 0.02^{a}$ & 0.0017 \\
\hline SS (N) & $2.02 \pm 0.01^{b}$ & $2.75 \pm 0.02^{\mathrm{a}}$ & $2.95 \pm 0.02^{\mathrm{a}}$ & 0.000 \\
\hline
\end{tabular}

Means with the same letter in the same column do not differ statistically at $5 \%$ (P>0.05); F1: formulation 1; F2: formulation 2; F3: formulation 3; L: Lightness; a: Redness; b: Yellowness; SS: Shear strength $(\mathrm{N})$; ${ }^{*} \mathrm{P}$ value at $5 \%$ difference $(\mathrm{P}>0.05)$ among them. However, they had the shear strength differed from the formulation without the enzyme $(\mathrm{P}>0.05)$, which showed the lowest value $(2.02 \mathrm{~N})$.

The shear strength increased with the addition of the transglutaminase, so that the formulation with $0.6 \%$ of added enzyme had the highest value for the shear strength $(2.95 \mathrm{~N})$. Thus, a better texture was observed with the increase in the shear strength of the sausages. This is because transglutaminase cross-links with most proteins (Yokoyama et al, 2004). This mechanism can be explained by the catalyst action of this enzyme in the acyl transfer reaction between the $\gamma$-carboxyamide of the peptides or residues protein glutaminates and a primary amine of isopeptides of other amino acids (Ferreira et al., 2012).

Even with a smaller addition of the enzyme, the formulation with $0.3 \%$ transglutaminase showed good results both in appearance and texture of the sausage. Sausages prepared with the addition of $0.3 \%$ transglutaminase presented the quality parameter necessary for this type of emulsified inlaid, compared to the sausages prepared with the addition of $0.6 \%$ of the enzyme.

Moreno et al. (2010) studied the effect of the addition of $0.5 \%$ and $1.0 \%$ of microbial transglutaminase in restructured product of hake. The obtained results showed that the lower concentration was sufficient to enhance the appearance and texture attributes of the products. Min and Green (2008) observed that a minimum concentration of $0.1 \%$ of transglutaminase was sufficient to increase the shear strength and the resistance to compression among pieces of meat of channel catfish (Ictalurus punctatus).

\section{Microbial analysis}

The microbiological evaluations were conducted to ensure the safety of the raw materials, and the efficiency of process of preparation of the sausages, before consumed by the panelists in the sensory evaluation. The results are within the established by Brazilian legislation (ANVISA, 2001), which establishes the absence of Salmonella sp. in $25 \mathrm{~g}$, and the maximum of $10^{3} \mathrm{CFU} \mathrm{g} \mathrm{g}^{-1}$ of coliforms at $45^{\circ} \mathrm{C}$. Then, sausages were utilized for the sensory evaluation of acceptance and purchase intention.

\section{Sensory analysis}

In Table 3 are presented the results of the sensory analysis of the sausages developed with MSM of hybrid sorubim.

According to Table 3, there was no significant difference on the scores for the attributes "colour" and "odor" ( $\mathrm{P}<0.05)$. The mean values ranged from "like moderately" and "like very much", and the comments related to the presence of the characteristic odor of fish-based products. On the other 
hand, there was a significant difference in the attributes "texture" and "taste" $(\mathrm{P}<0.05)$. The sausages added of 0.3 and $0.6 \%$ transglutaminase had higher values for these attributes in comparison to the sausages prepared without the enzyme $(\mathrm{P}<0.05)$.

Regarding the attribute "texture", the formulation without enzyme addition obtained 5.94 of averaged scores, ranging from "neither like nor dislike" to "somewhat like", while the sausages with addition of 0.3 and $0.6 \%$ of transglutaminase ranged from "like slightly" to "like moderately". This observed difference may be explained by the amount of enzyme added to the formulation and by its ability to improve the cohesion between the meat particles, resulting in the better texture of the products.

Muguruma et al. (2003) also reported that the texture of chicken sausages was improved with the addition of transglutaminase in the product. Pietrasik and LiChan (2002) reported that the addition of $0.5 \%$ of transglutaminase in beef gel samples resulted in greater firmness, hardness and cohesiveness than the products without the addition of the enzyme.
For the attribute "taste", the lowest average value (6.27\%) was obtained for the sausages prepared without the enzyme, which differed significantly $(\mathrm{P}<0.05)$ from the other formulations. Cavenaghi-Altemio et al. (2013) reported 'taste' average scores ranging from "like moderately" and "like very much" for sausages developed with MSM protein concentrate of Nile tilapia.

According to Dutcosky (2007), acceptance indexes above $70 \%$ represent a considerable acceptance of the analyzed samples. Thus, according to the results observed in Table 3, all of the attributes evaluated in the formulations containing transglutaminase were considered acceptable because the average values varied between the 79.86 and $84.03 \%$. In the formulation without transglutaminase, this index was not observed for the attributes "texture" and "taste", which varied between 65.97 and 69.68\%, respectively.

It was analyzed the purchase intention for the sausages elaborate with MSM of hybrid sorubins with the addition $0,0.3$ and $0.6 \%$ of the enzyme transglutaminase (Fig. 1 ).

Table 3: Mean values \pm standard deviation of the sensory evaluation of the attributes colour, odor, texture and taste of sausages prepared with mechanically separated meat of hybrid sorubins in relation to their transglutaminase content

\begin{tabular}{|c|c|c|c|c|c|c|}
\hline \multirow{3}{*}{$\begin{array}{l}\text { Parameter } \\
\text { Colour }\end{array}$} & \multicolumn{6}{|c|}{ Transglutaminase (\%) } \\
\hline & \multicolumn{2}{|c|}{0.00 (F1) } & \multicolumn{2}{|c|}{0.30 (F2) } & \multicolumn{2}{|c|}{0.60 (F3) } \\
\hline & $7.35 \pm 1.31$ & $(82.00)$ & $7.56 \pm 0.94$ & $(84.03)$ & $7.56 \pm 1.07$ & (84.03) \\
\hline Odor & $7.27 \pm 1.33$ & $(80.79)$ & $7.43 \pm 1.29$ & (82.64) & $7.18 \pm 1.35$ & (79.86) \\
\hline Texture & $5.94 \pm 2.01$ & (65.97) & $7.14 \pm 1.43^{\mathrm{A}}$ & $(79.40)$ & $7.35 \pm 1.30^{A}$ & (81.71) \\
\hline Taste & $6.27 \pm 2.29$ & (69.68) & $7.20 \pm 1.64^{\mathrm{A}}$ & (80.09) & $7.31 \pm 1.36^{A}$ & (81.25) \\
\hline
\end{tabular}

Means with the same letter in the same column do not differ statistically at $5 \%(P>0.05)$; F1: formulation 1; F2: formulation 2; F3: formulation 3 . Hedonic scale: $9=$ like extremely; $1=$ dislike extremely (see Material and Methods)

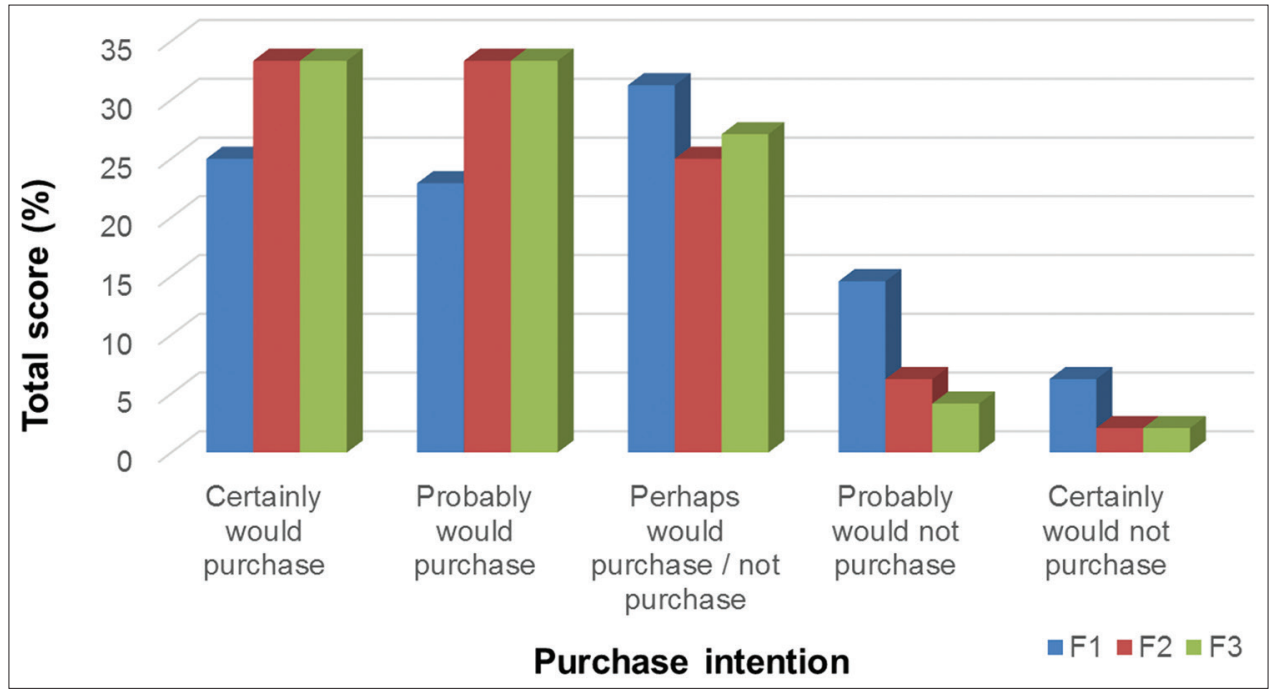

Fig 1. Percentage of purchase intention of the obtained sausages. F1: formulation; F2: formulation 2; F3: formulation 3 . F1 (in \%, w/w): 87.7 MSM of hybrid sorubim, 4.0 soybean protein concentrate, 2.0 cassava starch, $2.0 \mathrm{NaCl}, 1.7$ spices, 0.5 sodium erythorbate, 0.5 carrageenan, 0.5 sodium polyphosphate, 0.5 sodium nitrate, 0.4 sucrose, 0.2 cochineal carmine. $0.3 \%(\mathrm{w} / \mathrm{w})$ and $0.6 \%(\mathrm{w} / \mathrm{w})$ of the enzyme transglutaminase were added to $F 1$ in formulations $F 2$ and F3, respectively 
Sausages without the enzyme showed a purchase intention profile of $25,23,31,15$ and $6 \%$ for "certainly would purchase", "probably would purchase", "perhaps would purchase", "probably would not purchase" and "certainly would not purchase", respectively. By comparison, sausages with addition of 0.3 and $0.6 \%$ had $66 \%$ of consumer purchase intention for "certainly would buy" and "probably would buy" (Fig. 1). Thus, the addition of transglutaminase may be considered for MSM preparations due the well acceptance among consumers.

It was reported elsewhere that hamburgers prepared with transglutaminase differed statistically from the control sample and were considered of higher quality in terms of overall impression, verified in the acceptance test (Ferreira et al., 2012). Other authors found high acceptance rates of mousse $(60 \%)$ and soybean sausage $(80 \%)$ prepared with transglutaminase (Schäfer et al., 2011).

\section{CONCLUSIONS}

The addition of transglutaminase differed significantly in the chemical and physical properties of sausages prepared with transglutaminase addition: the protein content gradually decreased from 21.83 to $19.23 \%$ while the shear strength increased from 2.02 to $2.95 \mathrm{~N}$ with the transglutaminase addition. Moreover, the combination with salt and phosphate had a positive and synergistic effect on meat binding and on the oxidation of myoglobin present in meat, inhibiting lipid peroxidation and improving colour, being that the brightness, the yellowness and the redness increased with the enzyme addition ( 0.3 and $0.6 \%$ ). Sensory analysis indicated that sausages with transglutaminase addition presented increased acceptance rate and higher purchase intention.

\section{ACKNOWLEDGEMENTS}

The authors gratefully acknowledge the Brazilian research funding agencies CNPq and FUNDECT for their financial support.

\section{REFERENCES}

ANVISA. 2001. Brazilian National Health Surveillance Agency. Resolution RDC No. 12 of January $2^{\text {nd }}$ 2001. Available from: http://www.anvisa.gov.br/e-legis.

AOAC. 1995. Association of Official Analytical Chemists. $16^{\text {th }}$ ed. AOAC International, Washington, DC.

Baublits, R. T., F. W. Pohlman, A. H. Brown and Z. B. Johnson. 2005. Effects of sodium chloride, phosphate type and concentration, and pump rate on beef biceps femoris quality and sensory characteristics. Meat Sci., 70: 205-214.

Bligh, E. G. and W. J. Dyer. 1959. A rapid method of total lipid extraction and purification. Can. J. Biochem. Physiol., 37: 911-914.

Brazil. 2000. Normative Instruction $n^{\circ} .4$ of March $31^{\text {st }} 2000$ of the Brazilian Secretary of Agropecuary Defense from the Ministry of Agriculture and Supply. Technical Regulations of Identity and Quality of Mechanically Separated Meat, Mortadella, and Sausages. Official Gazette, Section 1, Brasília. p.6-10.

Cavenaghi-Altemio, A. D., L. B. Alcade and G. G. Fonseca. 2013. Low-fat frankfurters from protein concentrates of tilapia viscera and mechanically separated tilapia meat. Food Sci. Nutr. 1: $445-451$.

Cortez-Vega, W. R., Fonseca, G. G. and Prentice, C. 2015. Effects of soybean protein, potato starch and pig lard on the properties of frankfurters formulated from mechanically separated chicken meat surimi-like material. Food Sci. Technol. Int., 19: 461-471.

Dutcosky, S. D. 2007. Análise sensorial de alimentos. $2^{\text {nd }}$ ed. Editora Universitária Champagnat, Curitiba. p.239.

Ferreira, M. S., E. T. Mársico, R. J. Medeiros, C. R. Pombo, M. Q. Freitas, S. C. São Clemente and C. A. Conte Jr. 2012. Comparison of physicochemical and sensorial characteristics of beef hamburgers elaborated with sodium chloride, polyphosphate and transglutaminase. Rev. Bras. Med. Vet., 34: 52-60.

Fuentes-Zaragoza, E., J. A. Pérez-Alvarez and E. SánchezZapata. 2009. Effect of ingredients concentration upon colour of heat treated hake (Merluccius australis) batters. Opt. Pura Aplic., 42: 9-21.

Gaspar, A. L. and S. P. Góes-Favarini. 2015. Action of microbial transglutaminase (MTGase) in the modification of foods proteins: A review. Food Chem., 171: 315-322.

Granato, D., M. L. Masson and J. C. B. Ribeiro. 2012. Sensory acceptability and physical stability evaluation of a prebiotic soybased dessert developed with passion fruit juice. Ciênc. Tecnol. Aliment., 32: 119-125.

Herranz, B., C. A. Tovar, A. J. Borderias and H. M. Moreno. 2013. Effect of high-pressure and/or microbial transglutaminase on physicochemical, rheological and microstructural properties of flying fish surimi. Innov. Food Sci. Emerg. Technol., 20: 24-33.

Jiménez, A. and G. C. Gutiérrez. 2001. Métodos Para Medir Propiedades Físicas en Industrias de Alimentos. In: Alvarado, J. D. and J. M. Aguilera., editors. Editorial Acribia S.A., Zaragoza. p.325-346.

Keeton, J. T. 2001. Formed and Emulsion Products. In: Sams, A. R. Lewis Publishers, Boca Raton. p.195-226.

Kutemeyer, C., M. Froeck, H. D. Werlein and B. M. Watkinson. 2005. The influence of salts and temperature on enzymatic activity of microbial transglutaminase. Food Control, 16: 735-737.

Macedo, J. A. and H. H. Sato. 2005. Properties and applications of microbial transglutaminase. Alim. Nutr., 16: 413-419.

Marapana, R. A. U. and B. Jiang. 2004. Protein cross-linking in food by microbial transglutaminase (MTGase) and its application and usefulness in food industry. Trop. Agric. Res. Ext., 7: 49-61.

Min, B. and B. W. Green. 2008. Use of microbial transglutaminase and nonmeat proteins to improve functional properties of low $\mathrm{NaCl}$, phosphate-free patties made from channel catfish (Ictalurus punctatus) belly flap meat. J. Food Sci., 73: 218-226.

Moreno, H. M., J. Carballo and J. Borderías. 2010. Gelation of fish muscle using microbial transglutaminase and the effect of sodium chloride and pH levels. J. Muscle Foods, 21: 433-450.

Muguruma, M., K. Tsuruoka, K. Katayama, Y. Erwanto, S. Kawahara, K. Yamauchi, S. K. Sathe and T. Soeda. 2003. Soybean and milk proteins modified by transglutaminase improves chicken sausage texture even at reduced levels of phosphate. Meat Sci., 63: 191-197. 
Nielsen, G. S., B. R. Petersen and A. J. Møller. 1995. Impact of salt, phosphate, and temperature on the effect of tansglutaminase ( $\mathrm{F} \mathrm{XIIla)} \mathrm{on} \mathrm{the} \mathrm{texture} \mathrm{of} \mathrm{restructured} \mathrm{meat.}$ Meat Sci., 41: 293-299.

Oetterer, M. 2006. Proteínas do pescado processamento com intervenção na fração protéica. In: Oetterer, M., Regitano-D'Arce, M. A. B., Spoto, M. H. F., editors. Fundamentos de Ciência e Tecnologia de Alimentos. Manole, Barueri, SP. p.99-134.

Pedroso, R. A. and I. M. Demiate. 2008. Evaluation of the influence of starch and carrageenan on the physicochemical and sensory characteristics of cooked Turkey ham. Ciên. Tecnol. Alim., 28: 24-31.

Pietrasik, Z. and E. C. Y. Li-Chan. 2002. Response surface methodology study of the effect of salt, microbial transglutaminase and heating temperature on pork batter gel properties. Food Res. Int., 35: 387-396.

Rashchi, F. and J. A. Finch, 2000. Polyphosphate: A review. Their chemistry and application with particular reference to mineral processing. Min. Eng., 13: 1019-1035.

Schäfer, C., S. Neidhart and R. Carle. 2011. Application and sensory evaluation of enzymatically texturized vegetable proteins in food models. Eur. Food Res. Technol., 232: 1043-1056

Stone, H. S. and J. L. Sidel. 1993. Sensory Evaluation Practices. Academic, San Diego.

TBCA-USP. 2005. Brazilian Table of Food Composition. University of São Paulo, Brasil.

Tenuta Filho, A. and R. S. Jesus. 2003. Influence of washing tilapia minced on composition and acceptance of their products. Bol. Soc. Bras. Ciên. Tecnol. Alim., 37: 59-64.

USDA/FSIS. 1998. USDA/FSIS Microbiology Laboratory Guidebook. $3^{\text {rd }}$ ed. United States Department of Agriculture. Food Safety and Inspection Service, Washington, DC.

Uyhara, C. N. S., P. R. C. De Oliveira Filho, M. A. Trindade and E. M. M. Viegas. 2008. Addition of pigments to Nile tilapia frankfurters: Effect on sensory acceptance. Braz. J. Food Technol., 11: 271-278.

Yokoyama, K., N. Nio and Y. Kikuchi. 2004. Properties and application of microbial transglutaminase. Appl. Microb. Biotechnol., 64: $447-454$. 